\title{
The Image of the 'Saviour' in Waiting for Godot and Islam: A Thematic Comparative Study
}

\author{
${ }^{1}$ Ameer Abd Hadi \\ M.A. in English literature, Al-Qasim Green University (Iraq)
}

\section{ABSTRACT}

The idea of the 'saviour' has been an interesting subject matter for many specialists for a very long time. Its interset can be attributed to many reasons, probably the most important one is religion. Allusions to the saviour seem to be present in almost all religions, heavenly or earthly. It has been noted that even the pagan tribes believe in the existence of a saviour as a part of their cultures and traditions. Another reason stems back to man's weakness as a living creature and his constant need for a natural, or supernatural, power to save him from misery, oppression, injustice, ...etc. The saviour could be a superbeing or human being. For instance, Beowulf is looked at as a saviour, and King Arthur was, for a long time, thought to be a saviour that one day he will come and save his people, and many legends have been written in this respect.

The aim of this study is to highlight the 'saviour' as a concept in Samuel Becket's play Waiting for Godot and explore its interpretations as tackled by two 'schools': The Theatre of the Absurd and Existentialism, then compare it to the concept of the saviour from Islam's point of view.

The study falls into four chapters. Chapter one is devoted to outline the 'saviour' as a term, the belief in the presence of the saviour in general, and how the idea of the saviour is looked at by different writers and philosophers. Chapter two highlights the principles of the Theatre of the Absurd that are concerned with the 'saviour' and how those principles are reflected in the play. It also shows how 'waiting' becomes adherent to the word 'saviour'. Thereafter, the existentialism philosophy is examined since the principles of the Theatre of the Absurd are closely related to the it. Chapter three is spared for showing the concept of the saviour in Islam in general, and in the Shia sect in specific.

In order to accomplish this aim, some Quranic verses and Hadiths (reports of Prophet Mohamed's teachings collected after His death) are presented as examples to show the belief in the existence of the Saviour (Mahdi) in Islam.

Finally, the study ends with chapter four which, in the light of the research findings, compares the image of the saviour in Waiting for Godot and Islam.

Keywords:

saviour, Islam, waiting, Godot, Mahdi, image, comparative, Quran, Existentialism, Theatre of the Absurd Article Received: 18 October 2020, Revised: 3 November 2020, Accepted: 24 December 2020

\section{The Belief in the Presence of the Saviour} The word 'saviour' may refer to a person who helps people achieve salvation, or saves them from suffering and injustice at some point of time. ${ }^{1}$

One of the common mistakes in this respect is that the belief in the saviour is a purely religious one. This can be attributed to the fact that religions have strongly adopted this idea and that's why it has always been adherent to religion. But, many historians and sociologists confirm that the belief in the presence of the saviour is a general idea found in one way or another in human communities, though they differ in their belief according to each community's culture, religion, and nationality. The internationality of this idea is attributed to the esssence of the belief itself in the saviour which centers on the rise of a fair leadership that can lead people to justice and welfare and establish the right state in which people live equaly and peacefully. It can be traced back in Plato's The Ideal City, Al-Farabi's The Ideal People, Thomas More's Utopia, The New Atlanta for Francis Bacon, The Christian City for Yohan, The City of the Sun, for Tommaso Campanella, Confucius Island for the China wiseman Confucius ... etc. ${ }^{2}$

Furthermore, there are so many names for the saviour according to different religions and teachings, including: Messiah in Judaism, Saviour or Redeemer in Christianity, Mahdi (a nickname means 'gifted by Allah to creation') in Islam, Soter 
(derives from a Greek epithet), and Great General Utopus for Thomas More. ${ }^{3}$

Since the 'Saviour' is absent, waiting for that Saviour becomes the unifying factor for all of those 'believers' in the saviour. They all wait, and along with waiting, different interpretations emerge about who the saviour is, and the way he is expected to emerge. In Judaism, the Jewish Messiah, often referred to as "King Messiah" is expected to descend from King David and accomplish the unification of the twelve tribes into a re-established nation. According to Chirstianiry and the idea of the Second Coming of Juses Christ, He will return to earth after His "first coming" and ascension to heaven about two thousand years ago. He will come again in glory to judge the living and the dead, and His kingdom will have no end. Considering Islam's point of view, Mahdi is the prophesied redeemer of Islam who will rule on the earth and rid the world of evil and establish Heaven justice. ${ }^{4}$

It is noted that the very circumestances in which the idea of the saviour appears are those in which people are helpless and oppressed. Circumestances in which man doesn't believe in the material solution to save him and has no trust in the natural world, therefore, he starts seraching for a solution that lies beyond nature. Having set forth the 'saviour' and 'waiting' in brief, it is worth noting that such a theme has never been absent in litearture since litarerature is the mirror that reflects life.

In the early twenteth century, Bosnia and Herzegovina witnessed the first spark that turned into a great fire which burnt Europe and affected the whole world declaring The First World War in 1914 that never calmed down until over 17 million deaths and over 20 million wounded have been recorded, leaving thousands of cities and villiages destroyed as well as millions of lost dreams. Afterwards, as Europe was trying to recover from the catastrophic effects of the war, the Second World War was announced, not ended until a double of casualities and destruction were recorded.
The circumestances during, between, and after the I and II World Wars were very much suitable for many people to think of, and wait for, a saviour to uplift them from the madness they were living in. But, such 'thinking' and 'waiting' for the saviour were of a special kind formed as a result of some causes, one of them was the existentialist philosophy. Before going through the play, it is preferable to tackle the existentialist philosophy.

\subsection{Existentialist philosophy}

Existentialism is a philosophy concerned with finding self, individual existence and the meaning of life through free will, choice, and personal responsibility. The belief is that people are searching to find out who and what they are throughout life as they make choices based on their experiences, beliefs, and outlook. Personal choices become unique without the necessity of an objective form of truth. An existentialist believes that a person should be forced to choose and be responsible without the help of laws, ethnic rules, or traditions and there is no meaning in the world beyond what meaning people give it. Existentialism became popular in the years following World War II. ${ }^{5}$

Søren Kierkegaard is generally considered to have been the first existentialist philosopher who proposed that each individual, not society or religion, is solely responsible for giving meaning to life and living it passionately and sincerely, or "authentically". Later on, comes Jean Paul Sartre the prominent existentialist philosopher who adopts the term as a 'self-description' and claimed that a central proposition of Existentialism is that existence precedes essence, which means that the most important consideration for individuals is that they are individuals independently acting and responsible, conscious beings; thus, human beings, through their own consciousness, create their own values and determine a meaning to their life. Existentialism was an influential philosophy in Paris during the rise of the Theatre of the Absurd; however, to call it existentialist theatre is problematic. Theatre of the Absurd gained this association partly because it was named (by 
Martin Esslin) after the concept of "absurdism" advocated by existentialist philosophers. ${ }^{6}$

\section{The Theater of the Absurd}

The lexical definition of the word 'absurd' is "something that is completely stupid and unreasonable". The idea of the absurd entails that there is no meaning in the world and it is the man who gives it meaning. Thus, appears the adherence between Existentialism and the The Theatre of the Absurd. The Theatre of the Absurd is a post-World War II designation for specifc plays of absurdist fiction written by some of primarily European playwrights in the late 1950s. Their work focused widely on the idea of existentialism and expressed what happens when human existence has no meaning or purpose and is full of boredom and sufferings and, hence, communication breaks down; in fact alerting their audience to pursue the opposite. Logical construction and argument give way to irrational and illogical speech and to its ultimate conclusion, silence. The absurd in these plays takes the form of man's reaction to a world apparently without meaning, and/or man as a puppet controlled by invisible outside forces. This style of writing was first popularized by Samuel Beckett's play Waiting for Godot, 1952. ${ }^{7}$ In his play, Beckett depicted the image of the saviour in a special way, the lest one can say about it is that it is singular and unfamiliar.

\subsection{Who or What is Godot?}

"VLADIMIR: We will hang ourselves tomorrow. Unless Godot comes.

ESTRAGON: And if he comes?

VLADIMIR: We will be saved". 8

From the very beginning, the reader can feel that the play is based on two central things i.e., waiting and a waited character, expected to be a 'Saviour'. The two seemingly desparate characters Vladimire and Estragon are waiting for Godot whom they believe will save them.

One of the most frequently asked questions is who or what is Godot? This question is difficult to solve from the beginning to the end of the play and still it is a mystery in the literary academia. Becket himself did not put it clear. Once the director Alan Schneider asked him "who is Godot?" Becket answered, "If I knew I'd have said so in the play"'. This 'mysteriousness' has led many critics make different interpretations about Godot in a variety of ways. Some suggest that Godot stands for inaccessible God, others interpret it as death, some kind of future utopia, or a revolution and national liberation. But, what is sure about Godot is that he is looked at as a saviour. ${ }^{10}$

Although Godot is an offstage character, he is present throughout the play. Vladimir and Estragon remain faithful to him and he remains their only hope. But the more they talk and think about him, the more he becomes obscure, but certainly he represents a kind of a saviour that will come and change their miserable life, most likely, for the better.

\subsection{The Theater Absurd Interpretation}

“- What does he do, Mr. Godot?

- He does nothing, Sir."

The play presents a world in which daily actions are without meaning, language fails to communicate effectively, and the characters at times reflect a sense of artifice. The play does not tell a story; it explores a static situation. "Nothing happens, nobody comes, nobody goes, it's awful." The author's sense of mystery, anxiety and his despair at being unable to find a meaning in existence is obvious in the play: "Nothing to be done." In other words, nothingness is the saviour. The play largely focuses on the act of waiting as an essential and characteristic aspect of the human condition. However, the characters do not even know the exact reason of waiting for Godot.Vladimir and Estragon wait for Godot although their appointment with him is uncertain. Estragon does not remember it at all. Vladimir is not quite sure what they asked Godot to do for them. There is a constant stress on the uncertainty of the appointment with Godot, his unreliability and irrationality, and the repeated demonstration of the futility of the hopes pinned on him. The act 
of waiting for Godot is shown as essentially absurd. ${ }^{11}$

Godot is not Time, but he is associated with it, the one who makes but does not keep appointments. Perhaps Godot passes time with Gogo/Didi just as they pass it with him. Within this scheme, Godot has nothing to do (as the Boy tells Didi in Act II). Godot's continual absence wastes time in the lives of the tramps by making them living puppets in the world of the absurd. When Estragon and Vladimir stop talking, they must confront the emptiness of their lives, the fact that they have nothing to do but wait for Godot. Thus they are compelled to fill their time with absurd, often nonsensical conversations. ${ }^{12}$

Vladimir and Estragon's disappointment in Godot's arrival proceeds to the the extent that they consider the preferable act to waiting for Godot is suicide.

"We should have thought of it when the world was young, in the nineties... Hand in hand from the top of the Eiffel Tower, among the first. We were respectable in those days. Now it's too late. They wouldn't even let us up."13

Suicide remains their favourite solution but their disappointment at their failure to succeed in their attempts at suicide makes them forget about it. ${ }^{14}$

To sum up, waiting for the saviour is waiting for no one and nothing, and if there will be a saviour, that is nothing but death due to the emphasis of the Adsurd on pointlessness of existence.

\subsection{Existentialism Interpretation}

\section{“-I wasn't doing anything.}

-Perhaps you weren't. But it's the way of doing it that counts, the way of doing it, if you want to go on living." (p. 78)

According to the existentialist point of view, Godot has a function rather than meaning. He stands for what keeps us chained to and in existence, he is the unknowable that represents hope in an age when there is no hope; thus, he is the true saviour of mankind. Godot emerges as someone who appears to have considerable respectability and power in his community, in other words, Godot gives Estragon and Vladimir a sense of direction and purpose in their lives. Still Vladimir and Estragon live in hope: they wait for Godot,

"Tonight perhaps we shall sleep in his place, in the warmth, dry, our bellies full, on the straw. It is worth waiting for that, is it not?"

This passage, omitted in the English version, clearly suggests the peace, the rest from waiting, the sense of having arrived in a haven that Godot represents to the two tramps. They are hoping to be saved from the instability of the illusion of time, and to find peace and permanence outside it. Then they will no longer be tramps, homeless wanderers, but will have arrived home. Instead, they prefer to go on living their lives by saying things like, "we always find something to give us the impression that we exist". In this respect the play is read within the fundamental existentialist take on life. The fact that characters are constantly struggling to prove their existence. ${ }^{15}$

Godot has become a concept, an idea of promise and expectation, of that for which people are aware of the absence of meaning in their lives and they wait in the hope that it will restore significance to their existence.

"ESTRAGON: I wasn't doing anything.

VLADIMIR: Perhaps you weren't. But it's the way of doing it that counts, the way of doing it, if you want to go on living.

ESTRAGON: I wasn't doing anything.

VLADIMIR: Wait ... we embraced. ... We were happy . . . happy. What do we do now that we're happy ... Go on waiting ... wait” (p. 56).

The two tramps share the most profound life goal: determining a purpose for living which is clear in the very name of their quest, Godot. Godot is a contraction of their nicknames, Gogo and Didi, the inner self that might alternatively give cohesion to their lives. Godot, then, is that someone or something that represents the need of self-realization. For a brief moment, Vladimir is aware of the full horror of the human condition: "The air is full of our cries, but habit is a great deadener." He looks at Estragon, who is asleep, and reflects, "At me too someone is looking, of 
me too someone is saying, he is sleeping, he knows nothing, let him sleep on. ... I can't go on !" The routine of waiting for Godot stands for habit, which prevents us from reaching the painful but fruitful awareness of the full reality of being. ${ }^{16}$ Summing up, considering the existentialist interpretation, waiting for Godot is waiting for hope, recognition, and freedom.

Likewise, as far as we are informed, Godot is an old man with a white beard:

"VLADIMIR: (softly). Has he a beard, Mr. Godot?

BOY: Yes Sir.

VLADIMIR: Fair or ... (he hesitates) . . . or black?

BOY: I think it's white, Sir.”(p. 92-3)

The white beard may stand for wisdom, the quality that the characters need the most and wait to gain. From an existentialist point of view, man is the center of the world and existance precedes essence; hence, they deserve to live free from any confinements. They have the choice and they are responsible for that choice. On the contrary, Valdimir and Estragon have not realizied the reality behind their existence. They are lost in a chaos and wait for self-realization: Godot. Considering this quality as their saviour, they would be saved and live happily.

Due to the several allusions to the Bible in the play, the Christian point of view will be tackled in this chapter.

\subsection{Christian Interpretation}

"- And if we dropped him?"

- He'd punish us" (p. 92-3)

It has been suggested that Godot is a weakened form of the word 'God'. It has also been noted that the title En Attendant Godot seems to contain an allusion to Simone Weil's book Attente de Dieu (Waiting for God), which would create furthur indication that Godot stands for God. The significance of the syllable God cannot be denied in this context and Godot may be the unreachable God. In this sense, Godot is the path to eternity.
This idea of "eternity", an escape from death, suggests that if the tramps' intention is to find the way to eternity through Godot, and if they are certain that Godot is able to guide them, it would be advisable to invest their time in that hope. ${ }^{17}$

Written in the shadow of the Second World War, Godot seems to have deserted a world mutilated by barbarism. The dialogue has several allusions to events in the life of Christ as recounted in the New Testament. Every once in while Vladimir asks Estragon if he has ever read the Bible, particularly the accounts in the Gospels of the two thieves, and when his friend answers "no", he proceeds to lecture him on the mysteries of salvation and damnation. Throughout the play, there is much talk about prayers and supplications of goats and sheep, the beauty of the way and the goodness of the wayfarer, and of a personal God with a long white beard, like some pictorial representations of God in the West (or like a child's image of God) and that He keeps sheep and goats. ${ }^{11}$ Didi asks the Boy about Godot:

"VLADIMIR: (softly). Has he a beard, Mr. Godot?

BOY: Yes Sir.

VLADIMIR: Fair or . . . (he hesitates) . . . or black?

BOY: I think it's white, Sir.

VLADIMIR: Christ have mercy on us!"

Vldimir recalls the story of the two thieves and that both thieves will not be saved. He compares himself and Esragon to the two thieves and now, Vladimir seeks to protect himself:

"VLADIMIR:Tell him... (he hesitates) ... tell him you saw me and that ... (he hesitates) ... that you saw me ... You're sure you saw me, you won't come and tell me tomorrow that you never saw me!"

The "us" of the first act is the "me" of the second. This illustrates that Vladimir has taken Godot for God (or Christ) and he is afraid of His punishment:

"Estragon: And if we dropped him?

"Vladimir: He'd punish us," 
Beckett was asked about the theme of play, he sometimes refers to a passage in the writing of St.

Augustine:

"Do not despair: one of the thieves was saved. Do not presume: one of the thieves was damned." Vladimir states it right at the beginning: "One of the thieves was saved. ... It's a reasonable percentage." Later he enlarges on the subject: "Two thieves ... One is supposed to have been saved and the other... damned." 18

Godot himself is able of granting kindness and punishment; just like God. The boy who is his messenger minds the goats, and Godot treats him well. But the boy's brother, who minds the sheep, is beaten by Godot. "And why doesn't he beat you?" asks Vladimir. "I don't know, sir."19

After all, in support of the Christian interpretation, Godot is taken for Jesus Christ. Godot's white beard( refering to his holiness), His authority to set the time, place, terms of their appointment and ability to punish people are some pieces of evidence to this belief. $\mathrm{He}$ is also capable of granting hope through messeges of hope and His future arrival, sent by the Boy.

\section{The Islamic Belief in General}

The belief in a saviour of humanity is both Sunni and Shite belief, and they both believe that the saviour is Mahdi but they differ in who the Mahdi is. Followers of Sunni Islam and other minority Shi'as, believe that the Mahdi has not yet been born, and therefore his exact identity is only known to Allah (God).

Aside from the Mahdi's precise genealogy, Sunnis accept many of the same hadiths Shi'as accept about the predictions regarding the Mahdi's emergence, his acts, and his universal Caliphate (Islamic leadership). Furthermore, both Sunni and Shite believe that Jesus Christ will return alongside the Mahdi. ${ }^{20}$

According to the Islamic belief, the Mahdi's tenure will coincide with the Second Coming of Jesus Christ (Isa) "Jesus, the son of Mary (Isa Ben-Mariam), shall descend and pray behind the Mahdi", said the Prophet Muhammad."21, who is to assist Mahdi against the Masih ad-Dajjal (literally, the "false Messiah" or Antichrist). Differences exist in the concept of the Mahdi between Shia Muslims and adherents of the Sunni tradition. For Sunnis, the Mahdi is the Muslims' future leader who is yet to come. For most Shia Muslims, the Mahdi was born but disappeared and will remain hidden from humanity until he reappears to bring justice to the world, a doctrine known as the Occultation. For Twelver Shias, ${ }^{22}$ this "hidden Imam" is Muhammad al-Mahdi, the Twelfth Imam. ${ }^{23}$

\subsection{Mahdi}

Muhammad ibn Hasan, He is believed by Twelver Shi'a Muslims to be the Mahdi. He is believed to be an ultimate saviour of humankind that will emerge to fulfill His mission of bringing peace and justice to the world. He was born in 869 A.C. (15th Shaban 255 Hijri) in Samarra, Iraq. His father was the Eleventh Imam Hasan al-Askari and his mother was Narjis Khatoon, granddaughter of the Emperor of Rum. Imam Mahdi assumed Imamate (religious leadership) at 5 years of age following the death of his father Hasan al-Askari. In the early years of his Imamate he would only contact his followers through The Four Deputies. ${ }^{24}$ After a 72-year period, known as Minor Occultation, a few days before the death of his fourth deputy Abul Hasan Ali ibn Muhammad al-Samarri in 941, he is believed to have sent his followers a letter. In that letter he declared the beginning of the Major Occultation during which Mahdi is not in contact with his followers. ${ }^{25}$ Imam Ja'far al- Sadiq said: "There are two occultations for Qaem (another nickname of Mahdi). One is short and the other prolonged. In the short occultation only the special Muslims will know of his whereabouts. And in the longer occultation only his trustworthy servants will know where he is." 26

\subsection{Pre-emmergence of the saviour in Quran}

It is preferable to refer to the circumestances and signs that exist prior to the existence of Mahdi:

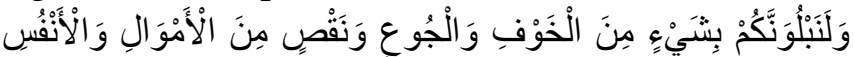

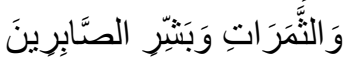


(سورة البقرة: الايه 155) - (سائ

"We shall test you with something of fear and hunger, some loss in goods or lives or the fruits (of your toil), but give glad tidings to those who patiently persevere."

( Al-Baqra Surah, ayat 155)

The great Hanafi scholar Muhammad ibn Muslim cites Imam Ja'far al-Sadiq explaining the meaning of the above Quranic verse:

Imam indicated that there would be signs indicating the coming (reappearance) of al-Mahdi (pbuh) which are the means whereby Allah tests the faithful. "'Something of fear" is a reference to masses perishing by contagious diseases;"hunger" is a reference to high prices of foodstuffs; "Some loss in goods" is a reference to scarcity and famines; "Lives" is a reference to mass destruction of human lives, probably global wars; "Fruits" is a reference to lengthy periods of draughts". ${ }^{27}$

Quran refers to some bad things to happen before the coming of Mahdi, fear, hunger, loss in goods and lives and fruits.

Another image shows the geographical scenary prior the coming of Mahdi:

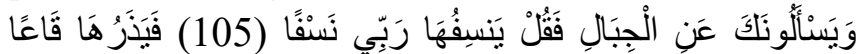

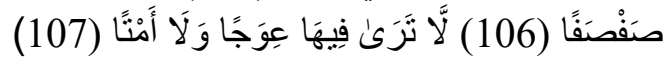

(And they ask you about the mountains, so say, "My Lord will blow them away with a blast (105) And He will leave the earth a level plain(106) You will not see therein a depression or an elevation(107).

In the above ayats, Quran clarifies that the earth will be completely plain and Allah will remove even the mountains or any kind of "elevation". ${ }^{28}$

A hadith by Prophet Mohamed:

"The Mahdi will be descended from me, He will fill the earth with equity and with justice, just as it has been filled with tyranny and oppression. "29 To sum up, the earth before the emergence becomes full of hunger, fear, famine, tyranny, oppression ...etc. Furthermore, it becomes flat, it as a wasteland in which man feels in loss. Such a setting is very similar to that presented by Beckett in Waiting for Godot.

\subsection{The Emergence of Mahdi}

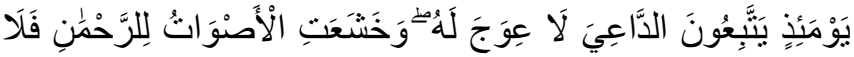

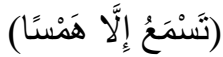

(108 الاية

/ b

(سورة

(That Day, everyone will follow [the call of] the Caller [with] no deviation therefrom, and [all] voices will be stilled before the Most Merciful, so you will not hear except a whisper [of footsteps]. Quran, Taha Surah/Ayat 108.

The Caller in this ayat is Mahdi who is going to call all peoples of the world for religion (Islam) and $\mathrm{He}$ will unite them as one nation. In this ayat, Quran uses the verb "follow" "يتبعون" to show peoples' complete belief in Mahdi and their willingness and ultimate trust in Him once they see Him. Furthermore, "no deviation therefrom" "لَ عِوَجَ لَهُ "لَّا", the Saviour is guided by Allah (God) so His emergence is expected to be highly sublime and majestic. ${ }^{30}$

Alem Subait Al-Nili believes that the plainess of the earth, which happens before the emmergence, is a preperation of the blossom to come with Mahdi because His emergence is conditioned with the modification of the earth which happens prior to His emergence to be ready for the exit of the blessings He is to bring with Him. In other words, $\mathrm{He}$ is to establish completely new rules and redesign the world's system all over again because it has been completely messed by the human being. 31

In another ayat, Quran continues to give references to the saviour by giving a sense of hope and good news for those who enduered oppression and tyranny:

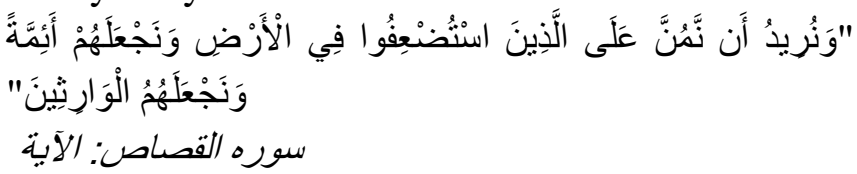

"And We desired to show favor unto those who were oppressed in the earth, and to make them leaders (in Faith) and to make them the inheritors."

Al- Qasas Surah, Ayat

4. Conclusions 
In the light of what has been presented above, one can say the followings:

The belief in the presence of a saviour is an international idea shared by many peoples in different nations and sects, and it is clearly present in religions, and the idea originally springs from man's search for a fair leadership.

There is a relative connection between the bad circumestances man undergoes and the ripeness of the idea of the saviour, i.e., wherever there is tyrrany, oppression, injustice, there is an urgent resort to a saviour. Furthermore, the image of the saviour could be a kind of escape man resorts to as a result of his suffering, it is a kind of salvation. Though ambiguity surrounds the identity of the saviour in Waiting for Godot, according to the 'philisophy' of the Theater of the Absurd, the saviour can be interpreted as death or an abstract idea which means 'nothing'. He is unknown, his real characteristics and geneology are ambiguous. He could even not be a human being. Whereas, the identity of the Saviour in Islam is not an abstract idea. Islam has given a concrete real shape to the saviour. In Islam, the identity of the the saviour Mahdi is known, his birth, geneology, his future message. The saviour is already there and people simply have to look for the day the circumstances are ripe for him to appear and begin his great mission. He appeared and disappearded three times and now he is in his long disappearance. According to the Islamic belief, Mahdi witnesses all the acts of oppression and injustice committed on earth. While, in Waiting for Godot, there is no reference to Godot's previous appearances. It is only a future prediction.

As for the setting in which the saviour is expected to appear, both Islamic belief and the play seem to meet in that earth becomes flat and messed up prior to the saviour's emergence. In addition, both of the play and Islam believe that people on earth will suffer hunger, fear, loss of goods and food, and these are symptoms of the saviour's near emergence.

The saviour's mission in Waiting for Godot is not clear. If he is to be looked at as a hope, which is one of the most accepted assumptions in the play, it is not clear how/what that hope is going to do to the oppressed. In other words, there is no map for his mission. On the other side, Islam has put some 'general lines' of the saviour's future mission after his appearance.

In both, Islam and Waiting for Godot, the saviour does not appear to speak. He is an offstage character talked about.

\section{Notes}

${ }^{1}$ Joseph A. Fitzmayer, The One Who is to Come (Cambridge, William B.E. Erdmans Publishing Company, 2007) p. 3.

2 'Alim Subait Al-Nili, Al-Tawr Al-Mahdawi ( Baghdad: Pluto Library for Printing and Publishing, 2003) p. 9.

${ }^{3}$ Fitzmayer, 3.

${ }^{4}$ Ibid.

${ }^{5}$ J.A Cuddon, A Dictionary of Literary Terms and Literary Theory, ed. M.A. Habib (West Sussex, Blackewll Publisher Ltd, 2013), p. 259261.

${ }^{6}$ Ibid.

${ }^{7}$ Martin Esslin, The Theater of the Absurd (London, Pelican Books, 1968), p. 23-4.

8 Samuel Beckett, Waiting for Godot (London, Faber and Faber Limitted,1956), p. 87. All the quutations in the research are taken from the above edition.

9 Alan Schneider, "Waiting for Becket" (New York: New York Times Archive, 1985) https://www.nytimes.com/1985/11/17/magazine/w aiting-for-beckett.html accessed July 10, 2018.

10 Harold Bloom, Samuel Beckett's Waiting for Godot (New York, Infobase Publishing, 2007), p.135-136.

11 Ronald Hayman, Contemporary Playwrights: Samuel Beckett (London, Heinemann Educational Books Ltd, 1968), p. 1112.

12 Martin Esslin, The Theater of the Absurd (London, Pelican Books, 1968), p. 45.

${ }^{13}$ Ibid.

${ }^{14}$ Bloom, p.143-5. 
15 Lawrence Graver, Samuel Beckett: Waiting for Godot (Cambridge, Cambridge University Press,1989), p. 79.

16 Ramji Lal, A Critical Study of Waiting for Godot (New Delhi, Rama Brothers India Ltd, 1977), p.101.

17 James L. Roberts, Samuel Beckett's Waiting for Godot \& Other Plays, ed. Gary Carey (New York, Hungry Minds, Inc., 1980), p 22-23.

18 Anthony Uhlmann, Samuel Beckett and the Pilosophical Image ( Cambridge, Cambridge University Press, 2006), p. 65.

${ }^{19}$ Bloom, p. 124.

${ }^{20}$ A. Toussi, Mahdi in the Quran According to Shi'ite Quran Commentators (Qum, Ansariyan Publications) p. 11.

21 Majlisi, Biharul Anwar: The Promissed Mahdi, trans. Sayyid Athar Husain S.H. Rizvi (Mumbai, Ja'fari Propagation Centre, Vol. 13), p. 295.

قال النبي (صل الله عليه واله) : " فينزل روح الله عيسى بن مريم فيصلي خلف المهدي."

${ }^{22}$ It is worth to mention that there are several branches of Shia Muslims the majority belong to "Twelver Shias". The term 'Twelver' refers to the twelve divinely ordained leaders, known as the Twelve Imams, whom Twelver Shia believes to be the rightous leaders of Muslims after prophet Mohammed, and they believe that the last Imam, Mahdi, lives in occultation and will reappear as the promised Mahdi.

${ }^{23}$ Toussi, p. 12.

24 Twelver Shias believe that Mahdi had four individuals (deputies). They served as a link between Mahdi and people during his minor occultation from 873-941 AD.

25 Al-SHykh Abu Ja'far Muhammad AlKulayni, Al-Kafi (Tehran, World Organization for Islamic Services, 1978, Vol. 6), p. 109.

قال رسول الله (صلى الله عليه واله وسلم) : "افضل العبادة انتظار

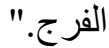

${ }^{26}$ H. Fereidouni, Imam Mahdi (A.S.): The Last Refuge of Human Beings, ed. Dr. Alaedin Pazargadi (Tehran, Naba Organization), p. 22.
${ }^{27}$ Muslim Ibn al-Hajjaj al-Naysaburi, Sahih Muslim, trans. Abdul Hamid Siddiqui (Riyad, Darussalam, 2007, vol.2), p. 56.

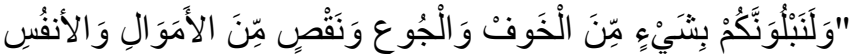

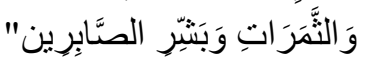

عن محمد بن مسلم عن أبي عبد الله جعفر بن محمد عليهما السلام

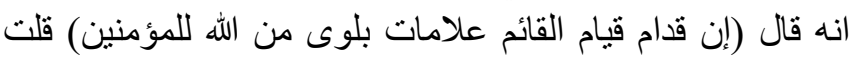
وما هي ؟ قال ذلك قول الله تعالى ( ولنبلونكم بشئ من الخوف التاف و الجوع ونقص من الأموال و الأنفس والثمرات (لثات وبشر الصابرين )

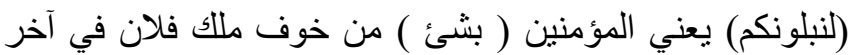

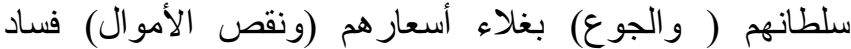
التجارات وقلة الفضل فيها ( والأنفس) موت ذريعاء (ونفيع ( والثمرات) قلة ريع ما يزرع وقلة بركة الثمار ( وبشر الصابرين) عند ذلاته

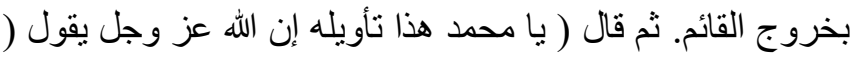
وما يعلم تأويله إلا الله و الر اسخون في العلم).

28 'Alim Subait Al-Nili, Al-Tawr Al-Mahdawi

( Baghdad: Pluto Library for Printing and Publishing, 2003) p. 56.

29 Majlisi, Biharul Anwar: The Promissed Mahdi, trans. Sayyid Athar Husain S.H. Rizvi (Mumbai, Ja'fari Propagation Centre, Vol. 13), p. 288.

قال النبي (صل الله عليه واله) : " المهدي مني ... يملأ الأرض قسطاً و عدلاً كما ملئت جوراً و ظلماً.

${ }^{30}$ Al-Nili, 54.

${ }^{31}$ Ibid. 56.

\section{References}

[1] Abul Fazl, M. (1910). The Translation of Holy Qur'an. Allahabad.

[2] Al-Gulpaygani, L. (1987). Discussions Concerning al-Mahdi. Qum: Islamic Humanitarian Service.

[3] Al-Kulayni, M. (1978). Al-Kafi. Tehran: World Organization for Islamic Services.

[4] Al-Naysaburi, M. (2007). Sahih Muslim. Riyad: Darussalam.

[5] An-Numani, M. Kitab al-Ghayba: The Book of Occultation. Qum: Ansariyan Publications.

[6] Beckett, S. (1956). Waiting for Godot. London: Faber and Faber Limitted.

[7] Bloom, H. (2007). Samuel Beckett's Waiting for Godot. New York: Infobase Publishing. 
[8] Cuddon, J.A. (2013). A Dictionary of Literary Terms and Literary Theory. West Sussex: Blackewll Publisher Ltd.

[9] Esslin, M. (1968). The Theater of the Absurd. London: Pelican Books.

[10] Fereidouni, H. Imam Mahdi (A.S.): the Last Refuge of Human Beings. Tehran: Naba Organization.

[11] Fitzmayer, J. (2007). The One Who is to Come. Cambridge: Erdmans Publishing Company.

[12] Fletcher, B. (1978). A Student's Guid to the Plays of Samuel Beckett. London: Western Printing Services LTD Bristol.

[13] Graver, L. (1989). Samuel Beckett: Waiting for Godot. Cambridge: Cambridge University Press.

[14] Hayman, R. (1968). Contemporary playwrights: Samuel Beckett. London: Heinemann Educational Books Ltd.

[15] Jeffares, A.N. (2002). Waiting for Godot. London: Gemayel Production and Printing.

[16] Lal, R. (1977). A Critical Study of Waiting for Godot. New Delhi: Rama Brothers India Ltd.

[17] Majlisi, M. Biharul Anwar: The Promissed Mahdi. Mumbai: Ja'fari Propagation Centre.

[18] Roberts, J. (1980). Samuel Beckett's Waiting for Godot \& Other Plays. New York: Hungry Minds, Inc.

[19] Robinson, M.(1969). The Long Sonata of the Dead: a Study of Samuel Beckett. London: Rapert Hart-Davis.

[20] Toussi, A. Mahdi in the Quran According to Shicite Quran Commentators. Qum: Ansariyan Publications.

[21] Uhlmann, A. (2006). Samuel Beckett and the Pilosophical Image. Cambridge: Cambridge University Press. 